THE RISE OF RUSSIA AND

THE FALL OF THE SOVIET EMPIRE 
This page intentionally left blank 


\section{THE RISE OF RUSSIA AND THE FALL OF THE SOVIET EMPIRE}

John B. Dunlop 


\section{Copyright $(C) 1993$ by Princeton University Press}

Published by Princeton University Press, 41 William Street, Princeton, New Jersey 08540

In the United Kingdom: Princeton University Press, Chichester, West Sussex

All Rights Reserved

\section{Library of Congress Cataloging-in-Publication Data}

Dunlop, John B.

The rise of Russia and the fall of the Soviet empire / John B. Dunlop.

p. $\mathrm{cm}$.

Includes bibliographical references and index.

ISBN 0-691-07875-0

1. Soviet Union-Politics and government-1985-1991.

2. Russia (Federation)-Politics and government.

I. Title.

DK288.D865 1993

947.085-dc20 93-1648 CIP

This book has been composed in Adobe Sabon

Princeton University Press books are printed on acid-free paper and meet the guidelines for permanence and durability of the Committee on Production Guidelines for Book Longevity of the Council on Library Resources

Printed in the United States of America

$\begin{array}{llllllllll}10 & 9 & 8 & 7 & 6 & 5 & 4 & 3 & 2 & 1\end{array}$ 
To John T. and Dorothy W. Dunlop 
This page intentionally left blank 